\title{
Life on Earth
}

At the launching ceremony in May for the Reader's Digest's 'augmented and enlarged edition' of David Attenborough's book of the film, Life on Earth, the publishers, at the suggestion of the author, presented a cheque for $£ 2500$ to Dr Sandy Harcourt for the Mountain Gorilla Project. This new edition of the book, published in conjunction with Collins and the BBC, is a truly magnificent production. The text is the same as in the edition published by Collins last year (at $£ 7.95$ ), but the choice of pictures is different, there are more, and the extra space (the page is half as wide again) has been adroitly used in several ways - to enlarge pictures, insert small ones and also for explanatory drawings such as this delightful one of a pseudoscorpion.(A spermatophore is a sperm sac.) The

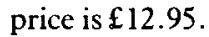

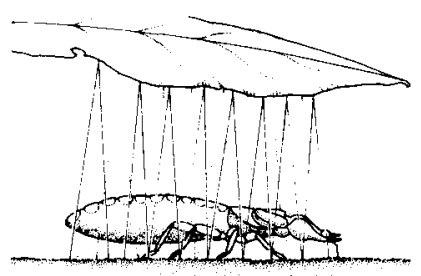

\begin{abstract}
A silken path The male Serianus carolinensis deposits a spermatophore after meeting a female. He then spins two rows of silken threads to form a path down which the female will walk. The path is wide at the beginning and narrows to the spot where the spermatophore stands
\end{abstract}

\section{Reports and Journals}

In the March issue of the quarterly fournal of Arid Environments K.E. Foster and N.G. Wright describe an unusual situation in water ownership and its effects. In Arizona all groundwater belongs to the landowner, and the city of Tucson has been buying and retiring farmlands, which has a considerable effect on the local economy. They suggest that a good alternative strategy would be to cultivate arid-adapted crops with an economic value, such as jojoba, whose seeds produce the valuable unsaturated oil. The sperm whale is the only other known source, and conservationists have for some time been advocating jojoba oil as the obvious alternative. Jojoba requires c. 4600 cubic metres of water per hectare; traditional crops in the area more than 12,000. (Annual subscription UK $£ 20$, overseas $£ 25$ : Academic Press.)

Silent Death by C.J. Cadbury is the RSPB's account and indictment of the deliberate misuse of poisons in the UK countryside between 1966 and 1978 and the indiscriminate (and illegal) killing that is the result. Fifty-three bird and six mammal species were victims: at least 89 buzzards died in the 388 incidents investigated, 9 golden eagles, 4 goshawks, 6 red kites, 4 peregrines, 13 badgers, 119 dogs and 42 cats. The RSPB would like to see much better enforcement of the law and some of the poisons much more strictly controlled, or withdrawn. 'Once sold there is no guarantee that these poisons will not be misused.'

Survival or Extinction, edited by Hugh Synge and Harry Townsend (Kew Gardens, Richmond, Surrey TW9 3AB, £7.50) is the proceedings of the 1978 Kew conference on the Practical Role of Botanic Gardens in the Conservation of Rare and Threatened Plants. In a foreword Dr David Munro, Director General of IUCN, points out that 'one principle emerges clearly: conservation in the wild is nearly always the most desirable policy'.

Hedges and Local History (Bedford Square Press, 95p) first published in 1971, is reprinted with some additional references. The title essay (there are four) is Dr M.D. Hooper's account of his method for assessing the age of an English hedge. 


\section{ORNITHOLIDAYS}

1980 Mesare o f rue sssocantox OF BRITISH TRAVEL AGENTS

HOLIDAYS ORGANISED BY

BIRDWATCHERS FOR BIRDWATCHERS

Ceylon

India (North)

India (Assam)

Florida

The Seychelles

Tanzania

Morocco

Malawi

Vancouver \& Rockies

The Gambia
S. W. Spain

Majorca

Greece

Yugoslavia

The Camargue

Lake Neusiedl

Austrian Alps

Portugal

Central Wales

Isles of Scilly

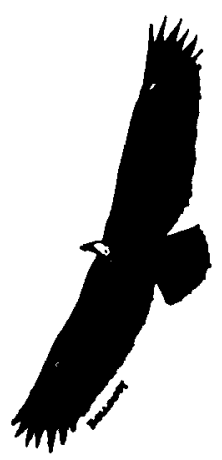

Isle of Mull

Isle of Islay

The Cairngorms

Hebridean Cruises

Dorset

Suffolk

Farnes \& Bass Rock

\section{LAWRENCE G. HOLLOWAY ORNITHOLIDAYS (Regd.)}

(WESSEX TRAVEL CENTRE)

1/3 VICTORIA DRIVE, BOGNOR REGIS, SUSSEX, ENGLAND PO21 2PW

Telephone 0243321230 


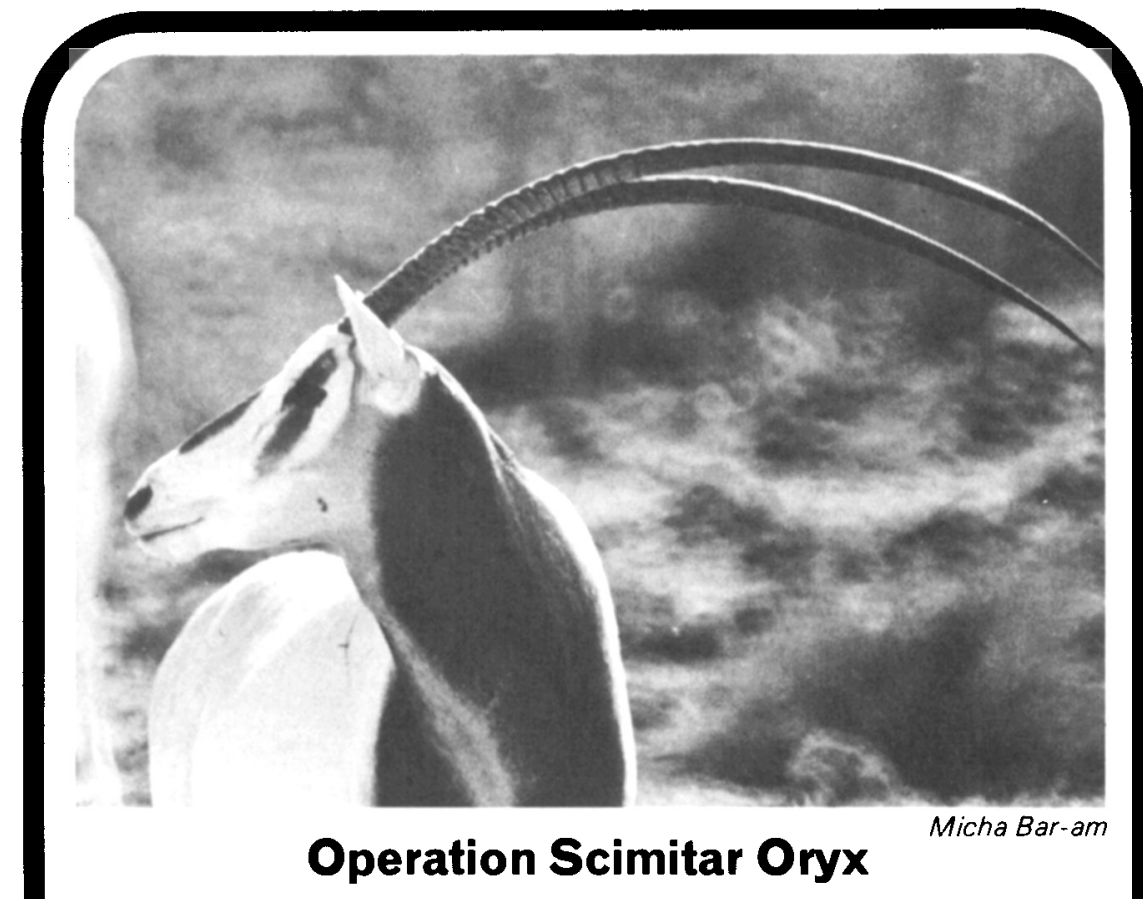

By 1990 scimitar-horned oryx may be extinct. Once spread throughout North Africa from the Nile to the Atlantic, now less than 2000 survive in scattered populations in Mali, Niger and Chad.

Despite their small numbers they are still hunted, especially where they compete with livestock for grazing; and in Chad, their stronghold, they may soon be exterminated because of the civil war there.

So FFPS started OPERATION SCIMITAR ORYX to save the oryx. John Newby, who has worked with them in the West African desert, is surveying the Termit area in Niger, aided by WWF, Marwell Preservation Trust and the Zoological Society of London, and preparing plans for a scimitar-horned oryx reserve.

Eventually, zoo-bred oryx from Britain will be taken to a breeding compound in Niger and their progeny will be released in the reserve.

\section{OPERATION SCIMITAR ORYX NEEDS $\$ 50,000$}

Please help to save this beautiful animal. Send your gift, however small, to FFPS, c/o The Zoo, Regent's Park, London NW1 4RY.

Operation Scimitar Oryx is a joint project of Fauna and Flora Preservation Society, Marwell Preservation Trust Ltd., People's Trust for Endangered Species, and Zoological Society of London. 


\section{Application for Membership}

\section{The Fauna \& Flora Preservation Society}

c/o The Zoological Society of London, Regent's Park, London NW1 4RY

Please enrol me as a member of the Society

Name (BLOCK LETTERS) Please state Mr/Mrs/Miss or title

Address

I enclose $\mathrm{f}$

being my subscription as a Life/Benefactor/Ordinary Member.

The minimum subscription for Ordinary Members is $€ 10$, US $\$ 20$, for Benefactors $€ 20$, US $\$ 40$, students $\mathrm{E} 5$, US $\$ 10$. A Banker's Order saves time, expense and reminders. The value of any subscription is greatly increased if it is paid under a seven-year Deed of Covenant (UK standard-rate income taxpayers only) and this entails no extra cost whatever: write for Covenant to the Secretary.

Life membership fees:

Age: Under 41, £350, US \$700; age 41-60 £300, US \$600; age 61 and over, f150, US $\$ 300$.

\section{Banker's Order}

\section{Bank}

Address of Bank

Please pay for the Credit of The Fauna \& Flora Preservation Society, Barclays Bank Ltd., Camden Town, London NW1, my subscription of $£$...................due on 1 st January 19 and a similar amount on 1st January each year until further notice. 


\section{Wildlife Film Library}

Unless otherwise stated all films are $16 \mathrm{~mm}$ colour with soundtrack. The charges quoted are for one screening only; additional screenings are $£ 2$, or $£ 1$ for older films. All films must be shown by an experienced projectionist with proper equipment. To book a film please write for booking forms to the Films Officer, Fauna and Flora Preservation Society, c/o Zoological Society of London, Regent's Park, London NW1 4RY (Tel: 01-586 0872).

Search for the Great Apes. Birute Galdikas-Brindamour with orang-utans in Borneo and Dian Fossey with mountain gorillas in Rwanda. 50 mins. $£ 7.50$.

Business of Extinction. A hard-hitting film dealing with trade in wildlife with particular reference to the Washington Convention. 50 mins. $£ 7.50$.

The Right Whale. An Endangered Species. Roger Payne's study of the right whales off Patagonia: National Geographic film. 22 mins. 17.50.

The Woodmen and the Wild. Management of woodlands and wildlife conservation. Filmed by Lord Dulverton, FPS Council member, on his own estate. 34 mins. $£ 7.50$.

At the Crossroads. American wildlife's struggle for survival. Shows endangered species never filmed before. Winner of six awards. 26 mins. $£ 7.50$.

The Last Stronghold. Flying snakes, flying squirrels, and other wildlife in the Malaysian rain forests. Made by WWF Malaysia. 30 mins. $£ 5$.

In Search of the Bowhead Whale. Aerial and underwater photography of bowhead and beluga whales off Alaska. 49 mins. $£ 5$.

Bighorn. Life history of Rocky Mountain bighorn sheep. 26 mins. £5.

Ivory Poachers. East African Wildlife society documentary of the fight against Tsavo elephant poachers. 30 mins. $£ 5$.

On the Third Day. Rare and beautiful plants, insects and vertebrates of the Cape of Good Hope. South African Wildlife Society. 26 mins. £5.

To Catch a Rhino. Translocation of white rhinos from the Umfolozi Reserve. South African Tourist Corporation, 1962. 20 mins. £3.

Everglades Region. How wildlife adjusts to seasonal fire and floods. 24 mins. $£ 3$.

Lake Wilderness. Wildlife of Saint Lucia Lakes. SATOUR. 20 mins. $£ 3$.

Blesbok. Life history of this South African antelope. 15 mins. £2.

\section{Older films}

$£ 2$ each or $£ 1$ if hired with a film from the main list.

Peace Game. South Africa's wildlife. SATOUR. 25 mins.

Saiga Saga. Conservation of the saiga antelope. Russian commentary with English subtitles: Soviet Peace Committee. 16 mins.

Koala. Complete life history. H.J. Pollock. 24 mins.

African Lion. Taken by A.I.M. Hepburn in the Kruger National park. Magnetic sound track. 12 mins.

Mallee Fowl. Nesting habits of a 'mound builder'. CSIRO Film Unit. 11 mins.

Marloo, the Red Kangaroo. By H.J. Pollock. 25 mins.

Le Aye Aye de Madagascar. Black and white. French commentary. By J.-J. Petter and the Service du Film de Recherche Scientifique. 22 mins.

Penguins of Macquarie Island. King, gentoo, rockhopper and royal penguins. 13 mins. 